\title{
The Effect of Financial Derivatives on the Financial Performance of Firms in the Financial Sector in Ghana
}

\author{
Dr. John MacCarthy \\ University of Professional Studies, Accra, Ghana, P. O Box LG. 149, Legon-Accra, Ghana
}

\begin{abstract}
This paper provides evidence on the impact of financial derivatives on the performance of firms in the financial sector in Ghana. Secondary data on financial derivatives, controlled business risks and business performance in terms of return on investment are used for the period 2011-2015. Data are sourced from 23 randomly selected financial firms in Accra, Ghana. A quantitative research technique is used to test four hypotheses. A strong positive correlation between financial derivatives and controlled business risks is found, $r(92)=.703, p<.05$. Also, there is a strong positive correlation between financial derivatives and business performance in terms of ROI, $r$ (92) $=.961, \mathrm{p}=.000$. This means that the financial performance of businesses improves largely when they trade in financial derivatives. Financial derivatives significantly predict business performance at 5\% significance level $(\mathrm{t}$ $=32.87, \mathrm{p}=.000$ ), where they account for $92.3 \%$ of the variation in business performance. Financial firms would, therefore, have to give priority to financial derivatives and their management to boost financial growth.

Keywords: Financial derivatives, business risks, financial firms, financial performance
\end{abstract}

\section{Introduction}

Many firms faced several risks in their operations. As firms in financial service sector operating activities become complex, the firms in the financial service sector find themselves increasingly exposed to business risks, with the exchange and interest rate fluctuations being just some of the financial risks they face. The management of these risks is fundamental to the performance of firms in the financial services sector in Ghana. Risks are part and parcel of every business. Yet, financial institutions and firms operating in money markets are more vulnerable to business risks relative to other firms such as service and product-centric firms (Gibson, 2007; Fadun, 2013). It is, therefore, paramount to hedge against risks to pave way for desired profitability, in order to avoid financial losses and bankruptcy. Common instruments used to manage and hedge against business risks by the financial institutions and firms in the money market are financial derivatives (Gibson, 2007; Hon, 2012). According to Cole (2009) the use of derivative instruments in corporate risk management is rapidly increasing in recent years and a situation that is caused by financial deregulations at a global scale and the evolvement of risks of higher weights in financial activities of financial firms during and after the global economic recession (Whitemann, 2003; Cole, 2009).

Today, many financial firms including banks use derivative instruments across the globe and there is the need for financial institutions to leverage them better to promote customer value and shareholders' returns (Kruase, 2007). Derivative instruments are contracts to buy or sell the underlying asset at a future time with the price, and quantity in the present specification. The firms in financial services sector trade in derivatives over- the- counter and as such there is high default rate by the participants in Ghana, as the Ghana stock exchange is at the moment not trading in derivatives on the exchange. As trading generally over-the-counter is inherently exposed to high default risk. This situation makes it risky using financial derivatives to manage risks in Ghana. Some of the financial derivatives used by the firms in the financial service sector include futures, options, swap, forward rate agreement (FRA) and forwards.

A number of empirical studies have shown that derivatives are relevant to business risks control. In the study of Krause (2007), the reducing effect of derivatives on risks is confirmed. In the same study, it is acknowledged that firms use financial derivatives to maximize profitability and to reduce the uncertainties associated with investments. In the mutual fund industry, Koski and Pontiff (1996) provided evidence on the role of derivatives on business risks reduction. Interestingly, empirical evidence on the use of derivatives to hedge business risks and to maximize financial performance is not limited to the financial services sector or money market. In the study of Muhrtala and Ogundeji (2013) conducted in Nigeria, it is confirmed that derivatives influence risk reduction among non-financial firms as well. By considering results in other studies (Wysocki, 1998; Whitemann, 2003), it is evident that derivatives impact business risk reduction. In a foreign country context, some studies (Cole, 2009; Bhagwat, More and Chand, 2012) have indicated that derivatives influence financial performance. This evidence makes a parallel with the fact that business risks are practically the major impediments to financial performance.

A review of academic literature on derivatives in the country indicates that researchers have given little attention to the corporate value of derivatives and their deployment in risks management. Research on derivatives revealed that, there is very few studies at the peer-reviewed level of journal publication. This therefore, makes academic debate on the subject very weak and discouraging, as the situation that does not reflect the weighty importance of derivative instruments for risk management by firms. This gap in the literature is wider in terms of the effect of derivatives on financial performance of businesses. Thus very few studies provide evidence on the 
effect of derivatives on financial performance. The few studies available on this subject are conceptual and theoretical. Relative to foreign countries, studies on the effect of derivatives on financial performance of firms are scarce in Ghana. This means that the gaps in the general literature are wider in a Ghanaian context. Academic debate on the subject in a Ghanaian perspective is, therefore, weaker. Based on this gap, this study seeks to examine the effect of derivatives on the financial performance of financial firms in Accra, Ghana. The study is limited to financial firms because access to needed data is only possible with these firms.

\subsection{The Problem Statement}

Generally, debates on the subject of derivatives and their effect on business risks and financial performance are weak in both theoretical studies and practice in Ghana. The problem is abysmal as there is very little empirical evidence available on studies conducted in Ghana's context. This problem has contributed to poor management of financial risks by many companies. This creates an urgent need to collect empirical evidence on the subject matter to validate conceptual and theoretical claims on the effect of derivatives on financial performance and business risks, especially financial performance.

\subsection{Objectives of the Study}

This study aimed to investigate the effect of financial derivatives on the financial performance of firms in the financial sector of Ghana in order to provide insight to the role of financial derivatives in the management of risk control in the financial sector.

\section{Literature Review}

The academic literature on derivatives and their effect on risk management and financial performance of firms are expanding in a slow pace. Before an overview of this literature is given, it is important to understand what derivatives are. The International Monetary Fund (1998) defined derivatives as complicated financial contracts that get their value from underlying assets. Primarily, a derivative is an agreement between a buyer and a seller that says how much the price of the asset will change over a specific period of time (IMF, 1998; Cole, 2009). In this respect, the underlying asset can be a commodity such as oil, gasoline or gold. Generally, many derivatives are based on stocks or bonds (IMF, 1998), while some firms use currencies, especially the U.S. dollar, as their underlying asset (IMF, 1998; Whitemann, 2003). There are also some firms which use interest rates as their base. By principle, these assets can be owned by either party, but this can also be avoided. This makes derivatives much easier to trade than the asset itself.

The primary purpose of the derivative instruments is not to borrow or lend funds but to transfer price lists associated with fluctuations, in asset values (Gangadhar \& Babu, 2009). Where there is volatility, there are those who believe they know what the next price movement is and back their judgement with money. Derivative contracts are a zero- sum game. What the buyer gains, the seller loses and vice versa. Derivative markets provide opportunities for three different kinds of participants: hedgers, speculators and arbitrageurs (Whaley, 2006). Derivative trade is a major dimension of firms' operation across the globe, including Ghana. According to Protess (2013), derivatives trading are now worth $\$ 600$ trillion; ten times more than the total economic output of the entire world. He further indicates that $92 \%$ of the world's 500 largest companies use them to lower risk. This information agrees with the current academic literature on the subject.

A good number of studies have shown that derivatives have a positive effect on reduced business risks. This means that trading in derivatives reduces the risks associated with businesses and their negative effect on profitability and financial performance. In India, the study of Bhagwat et al., (2012) confirms the reducing effect on derivatives on business risks. Cole (2009) also provides the same evidence from the viewpoint of many sectors and economies. In Nigeria, the same evidence is given with respect to non-financial firms by Muhrtala and Ogundeji (2013). Other studies (Remolona, Bassett and Geoum, 1998; Stulz, 2005; Whitemann, 2003) conducted in various countries provide results that support these evidences. In a foreign country context, some studies (Cole, 2009; Bhagwat et al., 2012) extend the relationship between derivatives and business risks to financial performance. Thus they indicate that financial performance is improved with effective derivatives trading. In essence, derivatives enhance profitability and financial performance just as they control and reduce business risks. The academic literature also indicates that business risks, once well hedged, lead to profitability and financial performance (Whitemann, 2003; Cole, 2009; Bhagwat et al., 2012; Muhrtala and Ogundeji, 2013).

\section{Research Methodology \\ 3.1 Sample and Data Research Analysis}

This study employed a quantitative research technique to test the hypotheses stated. The study selected 23 firms from 29 financial firms. The sample size was determined as outlined with the Krejcie and Morgan (1970). Probability sampling method involving the simple random sampling technique (balloting method) was used to select the 23 financial institutions as shown in Table 9 in the appendix of list of firms selected. The target 
population for this study was banks and financial firms in money market in Ghana. Also, firms that have secondary data on financial derivatives, risks and financial performance in terms of ROI were incorporated into the study. Secondary data is collected from a period of 4 years (2011-2015) for this study. This data that was collected from the participating banks and financial institutions is used to analyze hypotheses of this study. By implication, 92 data observations for each variable were incorporated into data analysis. Financial performance was captured from these participating institutions based on these firms' existing return on investment (ROI) data over the 4-year period of this study. Also, financial derivatives were captured from the secondary information on proceeds made from the firms' total derivatives for each year for the period 2011-2015. Controlled risks were captured from the firms' existing risks scores for the period. Data was analysed using SPSS version 21. This statistical software was used in view of its robustness for relational analysis. The study used correlational test and ordinary least square regression as analytical tools for this study. Pearson's correlation test was used to test the first three alternative hypotheses of this study while ordinary least squares regression analysis was used to test the fourth hypothesis. In the next section are results of the study.

\subsection{Research Hypotheses}

This study seeks to strengthen the foundation for academic debate on the subject in a Ghanaian point of view. In view of that, the study tests the following null hypotheses:

$\mathrm{H}_{1}$ : Financial derivatives are not positively related to hedged business risks.

$\mathrm{H}_{2}$ : Financial derivatives are not positively correlated to business performance in terms of return on investment.

$\mathrm{H}_{3}$ : Hedged or controlled business risks would not enhance business performance in the light of derivatives trading.

$\mathrm{H}_{4}$ : Business performance in terms of ROI cannot be expressed as a linear combination of financial derivatives.

\subsection{Findings}

To start with, this study seeks to examine the effect of financial derivatives on the financial performance of financial firms in Ghana. The goal in this section is to present results of this study. Results are presented based on the assumption that data used was drawn from a normal distribution. This assumption must be satisfied so that valid conclusions can be made in this study. Table 1 comes with the Shapiro-Wilk's test of normality. This test helps to identify if this assumption is satisfied.

Table. Normality Test

\begin{tabular}{|l|c|c|c|}
\hline & \multicolumn{3}{|c|}{ Shapiro-Wilk } \\
\hline & Statistic & df & P-value \\
\hline Financial derivatives ('000,000) & .222 & 92 & .443 \\
\hline Hedged business risks & .398 & 92 & .232 \\
\hline Business performance (ROI) & .181 & 92 & .674 \\
\hline
\end{tabular}

Source: Researcher's SPSS Version 21 Computation

Table 1 shows results of the Shapiro-Wilk's test of normality. This test is used to verify whether the normality of data assumption is satisfied. The default null hypothesis states that data associated with all variables in the table are normally or approximately normally distributed. This hypothesis is tested at 5\% significance level. We expect this hypothesis to be confirmed by the data so that a basis can be established for making a valid conclusion. If our data were normally distributed, the p-value of each variable would be more than the chosen level of significance, $5 \%$. From the table, the $p$-value for each variable is greater than $5 \%(p>.05)$. This means that the data normality assumption is satisfied for all data. A basis for making valid conclusions is, therefore, established.

In this study, it is argued that financial derivatives would only influence financial performance when they are able to hedge against business risks. It is, therefore, necessary to test the relationship between financial derivatives and hedged business risks. Table 2 comes with this test.

Table 2. Correlation between Financial Derivatives and Hedged Business Risks

\begin{tabular}{|l|c|c|c|}
\hline \multicolumn{2}{|c|}{} & $\begin{array}{c}\text { Financial derivatives } \\
\text { ('000000) }\end{array}$ & Hedged business risks \\
\hline \multirow{2}{*}{$\begin{array}{l}\text { Financial } \\
\text { derivatives } \\
\text { ('000000) }\end{array}$} & Pearson Correlation & 1 & $.703^{* *}$ \\
\cline { 2 - 4 } & Sig. (2-tailed) & & .000 \\
\cline { 2 - 4 } $\begin{array}{l}\text { Hedged } \\
\text { business risks }\end{array}$ & Pearson Correlation & 92 & 92 \\
\cline { 2 - 4 } & Sig. (2-tailed) & $.703^{* *}$ & 1 \\
\cline { 2 - 4 } & $\mathrm{N}$ & .000 & 92 \\
\hline
\end{tabular}

Source: Researcher's SPSS Version 21 Computation

Table 2 shows the correlation between financial derivatives and hedged business risks. The alternative 
hypothesis is that financial derivatives are positively related to hedged business risks. This hypothesis is tested at $5 \%$ significance level. At the chosen level of significance, this relationship is significant, $\mathrm{r}(92)=.703, \mathrm{p}=.000$. Thus, there is a strong positive correlation between financial derivatives and hedged business risks. This implies that financial derivatives impact the reduction of business risks at a high rate. Having confirmed this relationship, the next table contains results on the relationship between financial derivatives and business performance in terms of ROI.

Table 3. Correction between Financial Derivatives and Business Performance (ROI)

\begin{tabular}{|c|c|c|c|}
\hline & & $\begin{array}{c}\text { Financial derivatives } \\
(' 000000)\end{array}$ & $\begin{array}{c}\text { Business performance } \\
\text { (ROI) }\end{array}$ \\
\hline \multirow{3}{*}{$\begin{array}{l}\text { Financial } \\
(' 000000)\end{array}$} & $\begin{array}{l}\text { Pearson } \\
\text { Correlation }\end{array}$ & 1 & $.961 * *$ \\
\hline & Sig. (2-tailed) & & .000 \\
\hline & $\mathrm{N}$ & 92 & 92 \\
\hline \multirow{3}{*}{ Business performance (ROI) } & $\begin{array}{l}\text { Pearson } \\
\text { Correlation }\end{array}$ & $.961^{* *}$ & 1 \\
\hline & Sig. (2-tailed) & .000 & \\
\hline & $\mathrm{N}$ & 92 & 92 \\
\hline
\end{tabular}

Source: Researcher's SPSS Version 21 Computation

Table 3 shows the relationship between financial derivatives and business performance in terms of ROI. The alternative hypothesis states that financial derivatives are positively correlated to business performance in terms of ROI. As usual, this relationship is tested using 5\% significance level. At this chosen level of significance, the hypothesis is retained, $\mathrm{r}(92)=.961, \mathrm{p}=.000$. Thus, there is a strong positive correlation between financial derivatives and business performance in terms of ROI. This means that the financial performance of businesses improves largely when they trade in financial derivatives. It is, therefore, possible that hedged business risks also positively influence business performance. In Table 4, this expectation is confirmed.

Table 4. Correlation between Hedged Business Risk and Business Performance (ROI)

\begin{tabular}{|c|c|c|c|}
\hline & & Hedged business risks & Business performance (ROI) \\
\hline \multirow{3}{*}{ Hedged business risks } & Pearson Correlation & 1 & $.579^{* *}$ \\
\hline & Sig. (2-tailed) & & .000 \\
\hline & $\mathrm{N}$ & 92 & 92 \\
\hline \multirow{3}{*}{ Business performance (ROI) } & Pearson Correlation & $.579^{* *}$ & 1 \\
\hline & Sig. (2-tailed) & .000 & \\
\hline & $\mathrm{N}$ & 92 & 92 \\
\hline
\end{tabular}

Source: Researcher's SPSS Version 21 Computation

Table 4 shows the relationship between hedged (control) business risks and business performance. We expect that hedged business risks would promote business performance. At 5\% significance level, this expectation is confirmed, $\mathrm{r}(92)=.579, \mathrm{p}=.000$. In essence, business performance improves as business risks are increasingly reduced. Having observed the above relationships between financial derivatives and business performance, it is worthwhile to see if business performance can be expressed as a linear combination of financial derivatives.

Table 5 shows the descriptive statistics associated with firms' business performance and financial derivatives. From the table, the average business performance of the 23 financial firms in terms of ROI is $11.4 \%(\mathrm{SD}=6.1 \%$, $\mathrm{N}=92)$. Moreover, the mean proceeds of traded derivatives among the firms is $1,022,000(\mathrm{SD}=.65, \mathrm{~N}=92)$ for the period 2011-2015. The ROI value means that the financial firms achieved a net positive growth in the period. Table 5. Descriptive Statistics

\begin{tabular}{|l|c|c|c|}
\hline & Mean & Std. Deviation & $\mathrm{N}$ \\
\hline Business performance (ROI) & 0.1143 & 0.06059 & 92 \\
\hline Financial derivatives ('000000) & 1.022 & 0.6491 & 92 \\
\hline
\end{tabular}

Source: Researcher's SPSS Version 21 Computation

Table 6 shows the model summary of the prediction of business performance by financial derivatives. Financial derivatives account for $92.3 \%$ of the variation in business performance in terms of ROI.

Table 6. Model Summary

\begin{tabular}{|r|r|r|r|r|}
\hline Model & R & R Square & Adjusted R Square & \multicolumn{1}{|c|}{ Std. Error of the Estimate } \\
\hline 1 & $.961^{\mathrm{a}}$ & 0.923 & 0.922 & 0.01689 \\
\hline
\end{tabular}

a. Predictor: : (Constant), Financial derivatives ('000000)

Thus, about $7.7 \%$ of the variation is accounted by the error term and other factors. The variation accounted means that financial derivatives are strong determinants of business performance in terms of ROI among the financial firms in Ghana. 
Table 7. ANOVA $^{\mathrm{a}}$

\begin{tabular}{|c|l|c|c|c|c|c|}
\hline \multicolumn{2}{|l|}{ Model } & Sum of Squares & df & Mean Square & F & Sig. \\
\hline \multirow{3}{*}{1} & Regression & 0.308 & 1 & 0.308 & 1080.56 & .000 \\
\cline { 2 - 7 } & Residual & 0.026 & 90 & 0 & & \\
\cline { 2 - 7 } & Total & 0.334 & 91 & & & \\
\hline
\end{tabular}

a. Dependent Variable: Business performance (ROI)

b. Predictors: (Constant), Financial derivatives ('000000)

Table 7 shows the ANOVA test associated with the prediction of business performance. This test helps us to determine whether the regression analysis has improved our ability to express the relationship between financial derivatives and business performance in terms of ROI. At 5\% significance level, the test is significant, F $(1,90)$ $=1080.56, \mathrm{p}=.000$. This means that the regression analysis has improved our ability to express the relationship between financial derivatives and business performance in terms of ROI. In the next table are the coefficients of the regression analysis.

Table 8. Coefficients ${ }^{a}$

\begin{tabular}{|c|c|c|c|c|c|c|c|c|}
\hline \multirow{2}{*}{\multicolumn{2}{|c|}{ Model }} & \multicolumn{2}{|c|}{$\begin{array}{l}\text { Unstandardized } \\
\text { Coefficients }\end{array}$} & \multirow{2}{*}{$\begin{array}{c}\text { Standardized } \\
\text { Coefficients } \\
\text { Beta }\end{array}$} & \multirow{2}{*}{$\mathrm{t}$} & \multirow{2}{*}{ Sig. } & \multicolumn{2}{|c|}{$\begin{array}{l}95.0 \% \text { Confidence } \\
\text { Interval for B }\end{array}$} \\
\hline & & B & Std. Error & & & & $\begin{array}{l}\text { Lower } \\
\text { Bound }\end{array}$ & $\begin{array}{l}\text { Upper } \\
\text { Bound }\end{array}$ \\
\hline \multirow[b]{2}{*}{1} & (Constant) & 0.023 & 0.003 & & 6.882 & .000 & 0.016 & 0.029 \\
\hline & $\begin{array}{l}\text { Financial } \\
\text { derivatives } \\
\left({ }^{\circ} 000000\right)\end{array}$ & 0.09 & 0.003 & 0.961 & 32.872 & .000 & 0.084 & 0.095 \\
\hline
\end{tabular}

a. Dependent Variable: Business performance (ROI)

Table 8 comes with the coefficients of the regression analysis. It can be seen that financial derivatives significantly predict business performance at $5 \%$ significance level $(t=32.87, p=.000)$. Moreover, a unit change in financial derivatives changes the conditional mean of business performance by about $9 \%$ within a confidence interval of about $8 \%$ and $10 \%$. The relationship between financial derivatives and business performance can be expressed as: Business performance $=$ Financial derivatives $* 9 \%+2 \%$.

This model indicates that business performance can be expressed as a linear combination of financial derivatives. Since business performance is measured in terms of return on investment, it is worth saying that financial derivatives impact financial performance of financial firms in Ghana.

\subsection{Discussion of Findings}

Based on results obtained from this study, financial derivatives and controlled business risks are positively correlated, $\mathrm{r}(92)=.703, \mathrm{p}<.05$. To better put this result in perspective, one must bear in mind that "controlled business risks" would be different from "business risks", where the relationship with business risks would have been negative. The relationship found between financial derivatives and controlled business risks is largely supported in the current literature. Thus the literature (Whitemann, 2003; Cole, 2009; Bhagwat et al., 2012; Muhrtala and Ogundeji, 2013) suggest that trading in financial derivatives minimized or used to avoid business risks. Secondly, the main result of this study revealed that financial derivatives influenced positively business performance in terms of ROI, $r(92)=.961, p=.000$. Therefore, the relationship between financial derivatives and business performance is very strong and almost perfect. This implies that trading in financial derivatives would certainly enhance business performance in terms of ROI. The implication of this is that the participating firms used effective derivative trading measures. Though there is little evidence on this relationship, some studies (Cole, 2009; Bhagwat et al., 2012) have indicated that derivative trading positively influence financial performance. Though no identifiable evidence exists on it, this study also suggests that business financial performance can be expressed as a linear combination of financial derivatives.

A positive correlation between controlled business risks and financial performance is also found in this study, $\mathrm{r}(92)=.579, \mathrm{p}=.000$. This evidence is supported by the fact that financial performance increases with increasing reduced risks or as business risks reduces (Whitemann, 2003; Cole, 2009; Bhagwat et al., 2012; Muhrtala and Ogundeji, 2013). With respect to the current literature and personal experience, there is much evidence to say that trading in derivatives significantly reduces business risks, and therefore impacts business growth in terms of return on investment. But to buttress this study's results and its contribution to academic debate on the subject, there is the need for more empirical studies to be conducted on the subject.

\section{Conclusions and Recommendations}

\subsection{Conclusion}

A strong positive correlation between financial derivatives and controlled business risks was found, $\mathrm{r}(92)=.703$, 
$\mathrm{p}<.05$. Thus financial derivatives impact the reduction in business risks among the chosen firms. Also, there is a strong positive correlation between financial derivatives and business performs in terms of ROI, $r(92)=.961, p$ $=.000$. This means that the financial performance of businesses improves largely when they trade in financial derivatives. Moreover, business performance improves as business risks are increasingly enhanced, $\mathrm{r}(92)=.579$, $\mathrm{p}=.000$

Financial derivatives significantly predict business performance at $5 \%$ significance level $(\mathrm{t}=32.87, \mathrm{p}=.000)$, where they account for $92.3 \%$ of the variation in business performance. Moreover, a unit change in financial derivatives changes the conditional mean of business performance by about $9 \%$ within a confidence interval of about $8 \%$ and $10 \%$. The relationship between financial derivatives and business performance can be expressed as: Business performance $=$ Financial derivatives $* 9 \%+2 \%$. This model indicates that business performance can be expressed as a linear combination of financial derivatives. The four alternative hypotheses stated are all confirmed at 5\% significance level. Since business performance was measured in terms of ROI, it is concluded that financial derivatives impact financial performance among the chosen financial firms in Ghana. Since the firms were randomly chosen, it is likely that the result reflects a Ghanaian situation.

\subsection{Recommendations}

This study and its result provide evidence for using financial derivatives to boost financial performance through control of business risks. Businesses would, therefore, have to give priority to financial derivatives and their management. Furthermore, studies based on the impact of financial derivatives on financial performance are very few. This implies that more future studies on the subject are needed to form a strong academic debate on it and to buttress existing findings on it. Researchers are, therefore, encouraged to conduct similar studies to expand the subject's literature and its contribution to knowledge. Future researchers can conduct this study on non-financial sectors since this and many other studies have been based on the financial services sector.

\section{References}

Bhagwat, S., Omre, R., \& Chand, D. (2012). An Analysis of Indian Financial Derivatives Market and its Position in Global Financial Derivatives Market, Journal of Business Management \& Social Sciences Research, 1(2), 45-59.

Cole, L.J. (2009). Financial derivatives and the era before and after the economic recession, Journal of Financial Studies, 2(3), 22-34.

Fadun, E.S. (2013). Financial Services Sector Risks Management: The Derivatives Option, International Journal of Humanities and Social Science Invention, 2(1), 22-31.

Gangadhar, V., \& Babu, G. R. (2009). Investment management, New Delhi: Anmol Publications Pvt. Ltd.

Gibson, M.S. (2007). Credit Derivatives and Risk Management, Finance and Economics Discussion Series Divisions of Research \& Statistics and Monetary Affairs Federal Reserve Board, Washington, D.C., 2-16.

Hon, T. (2012). Managing Financial Risk by Using Derivatives: A Study of Hong Kong Listed Companies, White Paper Series, 2-26.

International Monetary Fund (1998). Financial Derivatives, Eleventh Meeting of the IMF Committee on Balance of Payments Statistics, 3-19.

Koski, J.L., Pontiff, J. (1996). How Are Derivatives Used? Evidence from the Mutual Fund Industry, School of Business Administration, University of Washington, 2-21.

Krause, H.H. (2007). How much are derivatives being used? A German Perspective, European Journal of Finance and Economics, 4 (3), 764-781.

Krejcie, R. V., Morgan, D. W. (1970). Determining sample size for research activities, Educational and Psychological Measurement, 30, 232-256.

Muhrtala, T.O., Ogundeji, M.G. (2013). Derivatives and Financial Risk Management in Nigeria: Evidence from Non-Financial Firms, African Journal of Scientific Research, 11(1): 662-540.

Protess, B. (2013). Banks Face New Checks on Derivatives Trading, New York Times, January 3, 2013.

Remolona, E.M., Bassett, W., \& Geoum, I.S. (1998). Risk Management by Structured Derivative Product Companies, Frbny Economic Policy Review, 17-38.

Stulz, R.M. (2005). Demystifying Financial Derivatives, the Milken Institute Review, Third Quarter, 20-31.

Whaley, R. E (2007). Derivatives: Markets, Valuation and Risk Management. New Jersey: John Wiley and sons, Inc.

Whitemann, J.G. (2003). Financial Derivatives and Lean Times: Risk management perspective, BIS Working Paper, 32, 67-77.

Wysocki, P.D. (1998). Managerial Motives and Corporate Use of Derivatives: Some Evidence, 3-32. 


\section{Appendix}

Table 9. List of Sources of Data

\begin{tabular}{|c|c|c|c|c|c|}
\hline SN & Banks & SN & Non-banks & SN & Insurance firms \\
\hline 1 & Ecobank & 12 & $\begin{array}{l}\text { GN Bank (Formerly First National Savings } \\
\text { \& Loans Limited) }\end{array}$ & 18 & $\begin{array}{ll}\text { SIC } & \text { Insurance } \\
\text { Company } & \end{array}$ \\
\hline 2 & CAL Bank & 13 & Ezi Savings \& Loans Limited & 19 & $\begin{array}{l}\text { Vanguard Assurance } \\
\text { Company }\end{array}$ \\
\hline 3 & $\begin{array}{l}\text { Ghana } \\
\text { Commercial Bank }\end{array}$ & 14 & Procredit Limited & 20 & $\begin{array}{l}\text { Provident Insurance } \\
\text { Limited }\end{array}$ \\
\hline 4 & $\begin{array}{l}\text { National } \\
\text { Investment Bank }\end{array}$ & 15 & Opportunity International Savings \& Loans & 21 & GLICO \\
\hline 5 & Zenith Bank & 16 & Dream Finance Limited & 22 & $\begin{array}{l}\text { Donewell Insurance } \\
\text { Co. Ltd. }\end{array}$ \\
\hline 6 & Fidelity Bank & 17 & Express Savings and Loans Limited & 23 & $\begin{array}{l}\text { Nsiah Insurance Co. } \\
\text { Ltd. }\end{array}$ \\
\hline 7 & Stanbic Bank & & & & \\
\hline 8 & UT Bank & & & & \\
\hline 9 & UniBank & & & & \\
\hline 10 & GT Bank & & & & \\
\hline 11 & UBA & & & & \\
\hline
\end{tabular}

